\title{
Employment, social justice and societal well-being
}

\author{
Joseph E. STIGLITZ*
}

\begin{abstract}
The purpose of economic activity is to increase the well-being of individuals, and economic structures that are able to do so are more desirable than those that do not. This proposition might seem anodyne, but on closer inspection it is far more complex. To be sure, all politicians - left, right and centre - pay homage to it. Yet, the policies that are pursued often turn out to be antithetical to it. Much of traditional economics has indeed provided considerable comfort to those politicians who have a different agenda, and created considerable confusion for those who are sympathetic.
\end{abstract}

A second proposition, also deceptively anodyne, is that for a large fraction of the world's population, work - employment - is important. For individuals who lose their jobs, it is not just the loss of income that matters, it is also the individual's sense of self. Unemployment is associated with a variety of problems and pathologies, from higher divorce rates, higher suicide rates to higher incidences of alcoholism. And the relationship is not just a correlation: there is a causal connection. Some individuals can keep themselves happy and gainfully "employed" without a job. But for many, employment - the fact that someone else recognizes their "contribution" by paying them - is important. ${ }^{1}$

This article aims to explain how standard economic theory reflected in much of the popular policy folklore - has served to undermine the above propositions or runs counter to them. The first section shows how policies based on a neoclassical view of the labour market

* Columbia University. This article is based on a lecture given at the International Labour Office on the occasion of the Global Employment Forum, held in Geneva from 1 to 3 November 2001. The author wishes to acknowledge helpful discussions with David Ellerman and Jerry Levinson, and financial support from the Ford and Rockefeller Foundations. The views expressed are solely those of the author, and not of any organization with which he is or has been affiliated.

1 These attitudes are, of course, socially determined; in Western societies, for instance, there is increasing demand by women to participate in the labour force, a demand which is not just a reflection of economic factors. 
ultimately weaken workers' bargaining position because of pervasive market failures. The next two sections critically discuss the welfare and employment implications of a wider set of policies - from capital market liberalization to pro-cyclical fiscal and monetary management which are pursued on the theoretical assumption that efficiency and equity/distribution can be dealt with separately. The fourth section is a plea for labour to be seen as an end in itself, not a means of production, and development as a transformation of society; while the fifth section looks at the role of the international community in setting the objectives of socio-economic development. A concluding section sums up the discussion and offers some policy proposals aimed at providing full employment and better working conditions.

\section{Labour and neoclassical economics}

One of the great "tricks" (some might say "insights") of neoclassical economics is to treat labour like any other factor of production. Output is written as a function of inputs - steel, machines, and labour. The mathematics treats labour like a commodity, lulling one into thinking of labour like an ordinary commodity, such as steel or plastic. But labour is unlike any other commodity. The work environment is of no concern for steel; we do not care about steel's well-being (though to be sure, we may take care that the environment does not lead to its rusting or otherwise adversely affect its performance characteristics). Steel does not have to be motivated to work as an input. Steel does whatever it is "told" to do. But management is generally highly concerned with motivating labour.

The distinction arises from labour's human aspect. Individuals decide how hard they work, and with what care. The environment affects their behaviour, including the incentives with which they are confronted. In standard theory, individuals contract to perform a certain job, and are paid if and only if they complete that job. It is assumed that contract enforcement is costless - partly because of the assumption that information exists about whether the task (which is specified in infinite minutia) has been completed. Yet, information imperfections abound in the economy, and these information imperfections have profound impacts on the way an economy behaves, a fact recognized by the 2001 Nobel Prize (which focused in particular on information asymmetries). While this is not the occasion to review all of the implications of information imperfections, I want to highlight three that are particularly germane to the theses of this article.

First, imperfect information leads to imperfect competition; but the striking result of our research was that even a little bit of information imperfection - even a small cost of searching for a new job, for instance - can have a large effect. Economists always knew that infor- 
mation was imperfect, but they hoped that a little bit of imperfection would only change the equilibrium in a small way, and that the imperfections were indeed small. These hopes were not based on analytical work, but rather on the realization that if these assumptions were not true, the models that economists have used for decades, and the conclusions derived from these models, would be of little relevance. To put it perhaps over-grandly, it would have made much of economic analysis obsolete overnight. The new information economics showed, however, that even a small search cost could enable the equilibrium real wage to fall from the competitive level to the monopsony level (see Diamond, 1971; Stiglitz, 1985b and 1987a).

Observers of labour markets had long been concerned with bargaining power asymmetries. Workers' mobility is limited; employees who are fired - e.g. because they demand higher wages or better working conditions - may have a stigma, making it difficult for them to obtain another job, even if employers do not act collusively (and there may be tacit collusion); credit market imperfections (credit rationing, which itself can be explained by information imperfections) can make it difficult for a worker who is unemployed to live well for long, putting the worker in a far more precarious position than the employer who has lost whatever rents were gained from the worker's labour. What our analysis showed is that, despite other market imperfections that may exist, these alone put workers in a decidedly disadvantageous position.

Second, imperfect information leads to unemployment: even when wages are so high that the demand for labour is less than the supply, wages will not fall; for if a firm lowers its wages, workers' effort or the quality of workers hired may decrease (or their turnover costs increase). To most of the world, this is hardly news. But to standard economic theory it is: neoclassical theory said that markets always clear; what seemed to be unemployment was nothing more than a sudden change in the demand for leisure. Information economics also emphasized that the decentralized adjustment process often worked imperfectly, leading to temporary unemployment rates which even exceeded the equilibrium unemployment rates associated with efficiency wages. Yet traditional theory paid no attention to this - after all, with perfect information it is easy to move to the new equilibrium whenever the economy is disturbed.

Third, information economics has challenged the traditional economic theory which argues that markets are self-adjusting and efficient, and that the nature of the equilibrium (and its efficiency) depends neither on distribution nor on institutions. To traditional economists, the law of demand and supply determines the allocation of resources (including incomes), not institutions like sharecropping. Issues of efficiency could thus conveniently be separated from issues of distribution. Information economics has challenged each of these propositions: 
Bruce Greenwald and I showed that when information is imperfect or markets incomplete - that is, always - markets are not even constrained Pareto efficient, i.e. that in principle, there existed interventions in the market which took account of the costs of information and of creating a market, and which made everyone better off (see Greenwald and Stiglitz, 1986). Our analysis found that there were pervasive market failures that might, in principle, be addressed by government intervention. The retort that we ignored information imperfections in the public sector was simply wrong. We took them into account. We had, in fact, gone further, and identified reasons which made government's information set, powers and constraints different from those of a decentralized private sector, and which provided an explanation for why, at least in principle, government might undertake welfare-improving actions (see, for example, Stiglitz, 1989).

We also showed that the nature of the equilibrium, including its efficiency, could well depend on the distribution of wealth. This can be seen most clearly in the case of simple agricultural economies, but in fact it holds true more generally. The agency problems associated with sharecropping arise because of the disparity between the ownership of land and capital. Problems of information asymmetry do not arise when workers work their own land. ${ }^{2}$

Whether there was a political agenda in the back of the minds of those who formulated and developed the neoclassical theories, I will not venture to guess. But it is clear that the theories proved convenient for those with a particular set of interests. If, as neoclassical theory claimed, one could separate out efficiency issues from equity, one could pursue a political programme that focused only on the former-saying that if society wanted to change the distribution of income through its political process, that was an issue which it could turn to at any time; regardless of one's views on equity, it then made sense to remove distortions in the economy which impeded efficiency.

In standard competitive models, any interference with the free workings of the economy had an adverse effect on efficiency, whether it was minimum wage laws or trade unions - which introduced imperfect competition in labour markets - or requirements on working conditions. After all, an employer who offered workers worse conditions would only be able to recruit by paying commensurately higher wages. Firms would therefore carefully balance the extra cost of improving the conditions against the extra wage costs of not doing so, and these extra wage costs represented the marginal benefit of improved working conditions. Interventions to enhance job security were criticized, not only when they were made by government, but even when they resulted from collective bargaining because they were perceived as evidence of

2 Though information asymmetries may still be important in credit markets. 
trade unions' monopoly power. Public pension schemes were also criticized, with payroll taxes seen as leading to higher labour costs and thus explaining the rise in unemployment.

It was, of course, inconvenient that many of the central propositions had little empirical support. Card and Krueger's (1995) work strongly demonstrated that minimum wage legislation does not have the serious adverse effect on employment predicted by the standard theory - and that it may even have a positive effect. But economic theory did not lend credence to many of the propositions either, even without recourse to modern information theories. Even if benefits did not depend on contributions, payroll taxes should largely be shifted backwards (except for minimum wage workers), and hence have no effect on employment; and to the extent that benefits depend on contributions, there may be little or no effect on labour supply (not even a positive one). But information economics explained clearly why market equilibrium was generally inefficient, e.g. why firms "undersupplied" contract provisions enhancing job security (see, in particular, Shapiro and Stiglitz, 1984).

In short, the mantra of increased labour market flexibility was only a thinly disguised attempt to roll back - under the guise of "economic efficiency" - gains that workers had achieved over years and years of bargaining and political activity. To be sure, sometimes unions may have more than corrected the imbalance of bargaining power that previously existed, and used their power to push for excessive protection for their members, at the expense of other workers in the economy. If that happens, however, the answer is not to pretend that in the absence of such protections, the competitive market place would lead to efficient or equitable outcomes; but rather to try to redress the imbalances.

While freedom of association and trade union rights are important in correcting the power imbalances that exist in labour markets, even workers enjoying such rights are typically in a disadvantageous position. It is far easier for an employer to replace recalcitrant workers than for employees to "replace" a recalcitrant employer, especially when the unemployment rate is high. Thus, there is an important role for government, e.g. in ensuring occupational health and safety.

\section{"Market-friendly policies": At whose risk?}

There is a range of other policies - sometimes seemingly quite remote from the labour market - which affect the outcome of the bargaining process. Capital market liberalization enhances the bargaining power of capital: effectively, it gives "capital" the right to announce that if it is taxed unduly, or if other measures that it dislikes are adopted, it will leave the country. It enhances the threat point of capital, and therefore tilts the outcome more in its favour. In the extreme, it 
means that capital cannot be taxed at all. Had similar measures been adopted to enhance labour mobility, they would have restricted the ability to tax labour as well (see, for example, Stiglitz, 1983a and 1983b). A well-known standard result in tax theory says that the optimal taxes should be inversely related to the elasticity of supply; capital market liberalization thus leads to a lower optimal tax.

"Labour market flexibility" and "capital market liberalization" may thus appear as symmetric policies, freeing up the labour and capital markets, respectively; but they have very asymmetric consequences - and both serve to enhance the welfare of capital at the expense of workers. So ingrained have these prescriptions become in the mantra of good policy that their distributional consequences have been almost totally ignored; and of course, if efficiency and distribution could be separated, as traditional theory argued they could be, the lapse might not have been so important.

It is not, of course, just that the advocates of these policies overlook the imperfections of competition and information. There are other market imperfections (some derived from imperfections of information) to which they turn a blind eye too. With imperfect insurance markets, individuals worry about the volatility of their income. They can smooth only imperfectly and often at great cost. Risk matters more than it would if markets were perfect. Indeed, surveys of poor workers suggest that insecurity is among their main concerns, and that instability is among the most important causes and manifestations of poverty (see World Bank, 2000). Yet, the so-called Washington Consensus has not only pushed policies which enhanced instability, but it has also pushed for the elimination of job security protections (which markets by themselves will often not provide).

Another important set of market imperfections concerns corporate governance. Managers of firms may not act in the interests of shareholders, majority shareholders may not act in the interests of minority shareholders and, more broadly, the concerns of other stakeholders may not be adequately reflected in the firm's decision-making process (see Stiglitz, 1985a).

The advocates of these "market friendly policies" (which might more aptly be called "capital market friendly" policies) have not consistently followed the neoclassical model's symmetries. For instance, they talk about the discipline provided by capital market liberalization - the discipline of a capricious market place, exhibiting not only irrational exuberance but, from time to time, irrational pessimism. Those who subject themselves to this discipline know too that it has particular perspectives and ideologies. Imagine how different the discipline might be if skilled labour, or unskilled labour, were perfectly mobile. It might, for instance, threaten to leave a country that did not provide adequate air quality, or which otherwise had a degraded environment. 
Another manifestation of "capital market friendly policies" is the recent push for privatization of social security, with the replacement of defined-benefit programmes by defined-contribution programmes. While this is not the occasion for a full debate on the issues, ${ }^{3}$ it should be clear that privatization would be of immense benefit to those firms that managed the pension funds and provided the annuities, but it would at the same time impose greater risks on workers, since the market in most countries does not provide securities that are fully indexed for inflation. Moreover, there is evidence suggesting that even in highly efficient capital markets, like the United Kingdom's, transaction costs are so high that benefits under privatization are reduced by 40 per cent (Murthi, Orszag and Orszag, 1999).

Advocates of the (capital) market friendly doctrines have not argued that all institutions do not matter. They argue that monetary institutions matter. Not content to change the broader economic environment in ways which tilt the balance of power, they have pushed for monetary institutions which tilt the balance of power further still, pressing for independent, non-representative central banks with a mandate solely for price stability. They try to use economic "reasoning" to support their conclusion, with regressions showing that countries with independent central banks have lower inflation. ${ }^{4}$ But they confuse ends with means - just as the entire enterprise which sees labour merely as input into production confuses ends with means. Inflation is of concern only to the extent that it leads to worse real outcomes, e.g. lower growth, more poverty, and greater inequality. And the link between independent central banks and these real outcomes is tenuous at best. ${ }^{5}$

Even if one believed that institutionally it is preferable to have an independent central bank, ${ }^{6}$ independence is not the same as nonrepresentativeness. One can have an independent central bank, in which the differing interests of different stakeholders are represented. It is not the case that there is a single Pareto dominant policy, ${ }^{7}$ one to which all "reasonable" people can agree. And so long as that is the case, one cannot - or, at least, should not - delegate decision-making to technocrats. Still less should one delegate decision-making to one group

${ }^{3}$ For a discussion of some of the fallacies underlying the standard arguments for privatization, see Orszag and Stiglitz (2001).

${ }^{4}$ New classical doctrines reinforced these perspectives: they argued that there was no trade-off in the long run. But even if there is no trade-off in the long run, there may be one in the short run. So long as the NAIRU is uncertain, different policy frameworks impose different risks (see Stiglitz, 1997).

5 One of the reasons is, of course, that it is hard to establish a significant adverse relationship between inflation and growth for low inflation economies (see Bruno and Easterly, 1996).

${ }^{6}$ The case for which I find more compelling in countries with a long history of high inflation than in those with no such history.

7 Though one strand of research in modern macroeconomics - that which contends that there is a vertical Phillips curve - has tried to argue something close to this. 
whose interests are markedly different from those of other groups. I shall return to this point at the end of the next section.

\section{Level of employment}

The previous section argued that there is a role for government in the labour market: at the minimum, ensuring the right to collective action and enforcing minimum standards. The notion that markets fail to ensure socially efficient (and desirable) outcomes has long been recognized. Keynes pointed out that there might be persistent unemployment. But by a sleight of hand, what came to be called the neoclassical synthesis (Samuelson, 1997) argued that, once we correct for the market failure of massive unemployment, markets work efficiently. Thus, the standard neoclassical model - with its implications of efficiency - prevailed. The neoclassical synthesis was simply an assertion, a hope, an attempt by those committed to the market model to limit the scope for potential government intervention. Bruce Greenwald and I argued that it was far more plausible to assume that there were pervasive market failures, of which massive unemployment was the most obvious manifestation, the tip of the iceberg that could not be ignored (Greenwald and Stiglitz, 1987). Research on the economics of information helped to explain what was wrong with the standard neoclassical model: why there could be equilibrium unemployment, ${ }^{8}$ why shocks to the economy could be amplified and result in the economy operating well below its "potential" for extended periods of time, and in the persistence of levels of unemployment far higher than the "equilibrium" level (see, for instance, Greenwald and Stiglitz, 1993).

Since Keynes and the Great Depression, few have believed in Say's law, that an increase in the supply of labour would automatically bring about an increase in demand. The theories referred to above explained how government intervention could help stabilize the economy with less volatility and higher equilibrium levels of employment. The precepts of counter-cyclical fiscal and monetary policy have come to be taught as part of standard macroeconomics in universities around the world. Remarkably, however, if we look at the data, we see that governments in less developed countries regularly engage in procyclical fiscal policies. Worse still, we have seen how the IMF has advocated fiscal and monetary tightening in the face of an impending recession. We have seen how these policies exacerbated the recessions in East Asia, helping to turn one into a depression, from which some have yet to fully recover. The IMF has also put in place strategies for financial market restructuring which have adversely affected macroecon-

${ }^{8}$ See the large literature on efficiency wages (e.g. Stiglitz, 1974 and 1987b; Shapiro and Stiglitz, 1984), much of which derives from problems of information imperfections. 
omic performance. In its structural adjustment programmes, it has often combined trade liberalization with interest rates so high that job and enterprise creation would have been impossible even in the best of economic circumstances, let alone in the more adverse circumstances prevailing in most developing countries. As the affected countries could not compete with the highly subsidized agricultural goods from the United States and elsewhere, the principles of comparative advantage did not play out in the way predicted by standard textbooks. Rather than moving from low productivity sectors to higher productivity, resources simply moved from low productivity to unemployment.

In transition economies as well, the policy framework all too often failed to lead to job creation. Even if the absence of a safety net implied that some employers did not fire their workers - resulting in less open unemployment than there might otherwise have been - it meant that they were underemployed, and often not paid. We now know the devastating effects - a GDP in Russia that is 40 per cent lower than ten years ago, and a poverty rate that has soared from 2 to 40 per cent or higher. Privatization, which was supposed to be the basis of wealth (and job) creation, laid the foundation for asset stripping and job destruction.

Repeatedly, we have seen a vicious cycle come into play: with excessively high unemployment rates, deteriorating social cohesion, accompanied by a multitude of societal manifestations from urban violence to riots and civil strife, creating an unattractive environment for investment and job creation. We saw that in Indonesia, where I predicted in December 1997 that if the highly contractionary monetary and fiscal policies that had been imposed on that country were maintained, there would be civil and political turmoil within six months. My prediction, unfortunately, proved all too correct.

While high interest rates prevent job creation, in the case of heavily leveraged firms large increases in interest rates contribute to job destruction - again as we saw in East Asia. They force firms into bankruptcy, and even if the resources eventually get reallocated (though in the process there may be considerable losses in assets and asset values), in the interim there can be high unemployment. And unfortunately, lowering interest rates at that point does not undo the damage: the bankrupt firms do not become unbankrupt. This is one of a number of important hysteresis effects within the labour market.

In development, transition and crises - or even in ordinary economic downturns - markets do not automatically quickly lead to full employment, and it is now almost universally recognized that government has an important role in facilitating employment creation and the maintenance of the economy at full employment. We now know a great deal about how to design effective stimulus programmes. We know that monetary policy is more effective in constraining an economy in a boom than in stimulating an economy in recession, and that 
we therefore need to rely on fiscal measures. We also know a great deal about how to design effective fiscal measures, i.e. measures which operate quickly, which have high multiplier effects, and which do not exacerbate social divisions in countries where such divisions are strong. ${ }^{9}$ An example might be policies which change intertemporal prices to encourage consumption and investment during a period of expected unemployment (in which the shadow prices of resources are low) and which reduce liquidity constraints that limit expenditures either on investment or on consumption. ${ }^{10}$ Such policies are indeed more effective than, say, tax cuts for the rich or permanent investment tax credits.

No matter how well we manage the economy, there will be downturns and, with downturns, unemployment. Yet while we know more about macroeconomic management, ${ }^{11}$ economic crises have become more frequent and deeper around the world: close to a hundred countries experienced crises in the last quarter of the twentieth century. I believe there are some reasons for this: changes in the global economic architecture, including capital market liberalization, have heightened risks beyond the coping ability of many developing countries. Thus, while countries need to be urged to construct adequate safety nets, ${ }^{12}$ anyone who is concerned with employment and decent work must be concerned about those features of the global economic architecture which contribute to volatility. Conversely, it seems perverse to argue simultaneously for measures that enhance global volatility and against measures that enhance worker security. Remarkably, however, this is precisely the position that advocates of the neo-liberal doctrines have taken.

The fact that there is a great deal of uncertainty in the dynamics of any economy implies that there is a great deal of uncertainty about the consequences of any policy. Today, for instance, we do not know how deep the recession will be, or would have been were it not for government intervention. All decision-making must take these risks into account; this entails a process of sequential decision-making, with policies revised as new information becomes available. But the policy structures must also take account of irreversibilities and non-linearities, such as the fact, noted earlier, that while small increases in interest rates

9 These are, of course, not the only desiderata that stimulus packages should meet: they should also strengthen the economy's long-run position, or at least not do undue harm.

10 The constraints themselves are explained by asymmetries of information (see, for example, Stiglitz and Weiss, 1981).

11 Indeed, in the United States, while there are still economic fluctuations, there is little evidence of a regular business cycle; expansions have become longer, and contractions shorter.

12. Though, at the same time, one should recognize the inadequacy of such safety nets - even in advanced industrialized countries - in the agricultural and self-employment sectors, sectors which predominate in less developed countries. 
may not force a company into bankruptcy, large increases may, with huge implications for the dissolution of organizational capital; and subsequent lowering of interest rates may not undo the damage. Different policies entail different risks, with the risks being borne by different groups within societies. Not surprisingly, the policies advocated by those with financial interests result in a disproportionate share of the risks being borne by workers.

In framing macroeconomic policies, we need to keep our eyes on the ultimate objectives, not on intermediate variables - i.e. on employment, growth and living standards, not interest rates, inflation rates or exchange rates. Such variables are important only to the extent that they affect the variables of fundamental importance. Typically, however, macroeconomic analysis is framed around a trade-off between a variable that is of direct concern - employment and output today - and an intermediate variable: inflation. It is asserted that higher inflation will lead to lower growth, though it is hard to find evidence of such a relationship being statistically and economically significant for countries which, like the United States, face low inflation. It is asserted that once inflation starts to grow, it will be difficult to turn it back - that the economy is on the edge of a precipice of price stability, from which it is easy to fall. Again, there is no evidence for this "precipice theory". Finally, it is asserted that once inflation begins, it is very costly to reverse. The evidence however, is to the contrary - that the "augmented Philips curve" is linear or convex, not concave, at least for the United States (Stiglitz, 1997).

No wonder then that there has been so little analysis of trade-offs between variables of fundamental concern: it is remarkably hard to establish such trade-offs. But even if one could, the analysis needs to focus on risks: what are the risks associated with excessively aggressive policies? With insufficiently aggressive policies? And who bears those risks? It should be clear that alternative policies force different groups within society to bear these risks. ${ }^{13}$ It follows then that macroeconomic policy is not a purely technical matter, and should therefore not be delegated to technocrats. It follows even more strongly that it is, to say the least, problematic to delegate decision-making to an independent central bank which is unrepresentative of the various groups affected by macro-policy, which is dominated by financial interests, and which pays little if any attention to employment.

${ }^{13}$ The nature of these risks depends, of course, on underlying structural relationships. For instance, if it is easy to reverse a slight increase in inflation (as the evidence seems to suggest) then one should be more willing to be more aggressive (see Stiglitz, 1997; Council of Economic Advisers, 1996 and 1997). 
A concern for employment and workers thus leads us to advocate not only for strong macroeconomic policies committed to the maintenance of full employment, policies which lead to greater economic stability, and strong safety nets to protect workers against the inevitable fluctuations that remain even with the best of economic policies, but also for institutional arrangements which ensure that the interests and concerns of workers are adequately reflected. Throughout the world, even social democratic governments have failed, by their acquiescence in unrepresentative and independent central banks. There is indeed little evidence to support the view that countries with independent central banks enjoy faster growth, high employment, higher living standards, or higher real wages (holding everything else constant). It is, of course, hardly surprising that an independent central bank focusing exclusively on inflation leads to lower inflation; but as I said before, inflation is only an intermediate variable. Besides, even if one agrees on independence, it does not follow that the mandate of the central bank should focus exclusively on inflation. I would argue that the Federal Reserve's broader mandate, which embraces employment and growth, has served the United States well. And if one argues that monetary policy should take account of employment and other objectives, it implies that if the central bank is independent, it should not be dominated by financial interests; workers should have a voice, and an important one at that.

\section{Labour as a means versus an end, and development as a transformation of society}

While much of this article focuses on economic analysis - e.g. institutions and policies which contribute to increasing employment, and of the inadequacies of the neo-liberal model - I would be remiss if I failed to note that what is at stake is not just models of how the economy works but also objectives. As noted earlier, much of the neo-liberal doctrine has seen labour solely as an input into production, an input just like any other input. But if improving living standards is the objective of economics, then improving the welfare of workers becomes an end in itself; and only if one believes that the market leads to efficient outcomes can one feel confident in not paying explicit attention to workers' welfare, trusting that the market will make all the correct tradeoffs. ${ }^{14}$

Elsewhere (Stiglitz, 1998), I have argued that development is more than just the accumulation of capital and the reduction of distortions

14 While I have focused on several of the market failures, there are others, especially relating to education and training, with imperfect contracting (see, for example, Arnott and Stiglitz, 1985). 
(inefficiencies) in the economy. It is a transformation of society, a departure from traditional ways of doing things and traditional modes of thinking. If development were mainly a matter of capital accumulation, then successful development would entail primarily making a country more attractive for capital, enhancing the "security" of capital. 15

If, however, development is to be broader based, then we must pay at least as much attention to workers and their security. We must persuade them that change can benefit them. But if they are exposed to increased insecurity and higher unemployment it will not; and many of the "reform" policies have done exactly that. On a more positive note, successful democratic development entails questioning authority and participation in decision-making: democratic workplaces ${ }^{16}$ as well as democratic political processes. These entail more democratic governance structures at all levels. ${ }^{17}$

\section{The role of the international community}

The principles set forth in this article so far are hardly radical, though in the terms of market-fundamentalist doctrines, which prevail in certain circles, they might seem so. This last section on the role of the international community begins with a simple premise, which should not be controversial either, though I am afraid it may appear to be so. That is, the international community should not push policies that contravene the above principles. Yet, that is precisely what the international community has been doing, through the Washington Consensus policies that have prevailed within the international economic institutions. They have pushed macroeconomic policies that have resulted in unnecessarily high unemployment, with pro-cyclical monetary and fiscal policies, the worst and most dramatic manifestations of which were witnessed in East Asia. To those who have worked in developing countries, however, their effects have been clear for years. The international economic institutions have pushed

15 We put aside here the question of whether the actual policies which the IMF has pushed have actually succeeded in doing so; arguably, capital market liberalization, while it has opened up access to capital, has also led to increased volatility, a higher incidence of crises, and in that sense, at a global level, may have actually not increased capital's "security". There are some who argue that the intent was not so much to increase the security of capital as the returns to capital. Increased capital mobility, as already noted, limits the scope for the taxation of capital, and, given the higher ability of higher income individuals and large corporations to bear risks, the increased riskiness of the global economic environment redistributes income in their favour.

16 There is some evidence that more democratic workplaces enhance economic efficiency (see Blinder, 1990; Levine, 1995).

17 By contrast, IMF conditionality often serves to undermine democratic processes, especially when (as in Korea) the conditionality extends beyond issues directly related to the crisis, and into core political issues (see Feldstein, 1998). 
financial policies that have replaced automatic stabilizers with automatic destabilizers: as economies go into recession, non-performing loans increase, and strict enforcement of capital adequacy standards forces banks to cut back credit, automatically accelerating the decline. They have pushed privatization of old-age pensions: this exposes the elderly to risks from which they might otherwise have been protected and imposes transaction costs which, while enriching the providers of financial services, markedly diminish the benefits received by the elderly. They have not only pushed policies like capital market liberalization which expose countries to enormous risks they cannot manage well, but they have also pushed "labour market flexibility", making workers bear more fully the brunt of the adverse consequences of those policies. They have opposed, or at least not supported, demands for rights to collective action on the argument that this would intrude into politics - though in a myriad of other contexts, they feel perfectly comfortable doing so. This is not the occasion to try to explain why the institutions in question have taken such stances, though given their governance structure they can hardly come as a surprise: they are run by finance ministers and central bank governors, whose interests, perspectives and ideology are often not fully sympathetic with the concerns of workers.

But I think the international community should go further. The IMF was established more than a half century ago out of fear that, as the Second World War came to an end, the world would once again sink into a global recession. The IMF was supposed to put pressure on countries to pursue expansionary policies - recognizing that a downturn in one country has spillover effects on others (a negative externality) and to provide the resources with which that could be done. It has not only abandoned its original mandate; it has, perversely, taken up the opposite cause, all too often providing funds to countries only on the condition that they engage in contractionary policies. As noted earlier, many developing countries have pro-cyclical fiscal policies. All too often this perversity arises not from a lack of knowledge of modern economics, but from a lack of resources. As the expression goes, banks love to lend to those who do not need their money; so when developing countries go into recessions, they pull their loans, exacerbating the downturn. Thus, developing countries may not only face exorbitant interest rates - with risk premiums that reflect an irrational pessimism which is the counterpoint to the excessive exuberance of the boom they may also find themselves unable to access credit. There is now considerable support for the hypothesis that there may be credit rationing (Eaton and Gersovitz, 1981), the presence of which can be explained by theories of imperfect and asymmetric information (see, for example, Stiglitz and Weiss, 1981). The presence of such credit rationing (sometimes referred to as liquidity constraints) provides the rationale for the 
IMF: why an international public institution is required. But unfortunately, rather than providing needed liquidity to developing countries to enable them to pursue full employment policies, the IMF typically provides liquidity to countries only on the condition that they pursue contractionary policies.

But there is a more fundamental criticism of IMF strategies, one which focuses on countries' trade deficits. Countries with large trade deficits are told to cut them back, but never is a word of criticism levelled at the countries maintaining sustained trade surpluses. If deficits are vice, then surpluses must be virtue. How different from Keynes' conception: it was then surplus countries that were seen as the source of the problem, as their insistence on high levels of savings contributed to "underconsumption" and an insufficiency of aggregate demand, which threatened global prosperity. There was even discussion of imposing penalties on surplus countries.

The more modern IMF seems to have missed a central point: the sum of all trade surpluses and deficits must add up to zero, so if some countries - like Japan and China - insist on having large surpluses, other countries must have correspondingly large deficits. The deficits are like hot potatoes. As one country is forced to eliminate its deficit, it must show up somewhere else in the system. With a focus on trade deficits, no wonder there is always an impending crisis somewhere in the world.

These issues have taken on a greater urgency today as the world is slipping into a major slowdown. The issue is not whether growth will be negative: the point is that the global economy is performing markedly below its potential, and the gap will inevitably result in increases in unemployment.

There is a simple remedy. As has just been observed, problems of insufficiency of global aggregate demand were very much on the minds of Keynes and others at the time the IMF was established. There is a framework for enhancing aggregate purchasing power, namely through the creation of Special Drawing Rights (SDRs). One way of thinking about this is the following: assume that the nations of the world wish to maintain reserves equal to a fixed percentage of their GDP; with global GDP of around US $\$ 40$ trillion and growth of around 2 per cent, if reserves were equal to 5 per cent of GDP, aggregate reserves would grow by US $\$ 40$ billion a year. Given the surpluses of China and Japan, a number twice that size might be more realistic. An annual issue of SDRs in that amount would just offset the purchasing power set aside in reserves and thus not be inflationary. The SDRs could be used to pursue global interests - from helping the poorest countries to improving the global environment.

For the past several decades, the IMF has focused on bailing out creditors and pushing the neo-liberal agenda. The time is ripe for the 
IMF to return to its original mission - i.e. ensuring global liquidity, to enable sustained global growth and, with that growth, full employment. But I think the international community should go still further: it is not enough just to do "no harm", or to have the IMF return to its role in promoting global economic prosperity. The international community should push for decent work, for full employment and better working conditions. Today there is international surveillance of countries in terms of their conformity to international norms for macroeconomic policies and financial institutions. The IMF's Article IV Consultations have grown beyond a review of whether countries are complying with the articles of agreement, to an intrusive review of a variety of policies. But while some macroeconomic indicators get enormous attention, others, such as the level of employment, the level of wages and disparities in pay, are virtually ignored. I believe very strongly that information helps shape behaviour: if we focus on unemployment, we will almost inevitably seek to ensure that it remains within reasonable limits, and if it does not, we will inquire into why not. If we demand that there be a "labour impact statement" before programmes (such as structural adjustment programmes) are adopted, then it is more likely that policies which minimize the adverse impacts on workers will be adopted.

Labour market experts must conduct the reviews. It is high time that we recognize that there are trade-offs in economic policies, that there is not a single Pareto-dominant policy. We should also recognize that there is a great deal of uncertainty about the consequences of economic policies and that there is, perhaps unsurprisingly, a correlation between those with particular perspectives/interests and the dominant views of the economy. It was those from the financial community who were the most ardent advocates of capital market liberalization, sliding over both the absence of compelling empirical and theoretical evidence that it increased growth and the presence of compelling evidence that it increased instability. Within the economics profession, labour economists are the most sceptical about claims that even moderate minimum wages result in significant unemployment. But even if one does not accept the Card and Krueger (1995) findings that there is no adverse effect, their results make a compelling case that if there is an adverse effect, it is not large.

We need a new framework for Article IV Consultations, one that is conducted with greater openness and transparency, with broader participation. These consultations would serve not to impose conditions on countries, but rather to enhance the kinds of dialogue on economic policy that should be central to democracy.

This may be a modest reform, but it is a small step that we can take towards the creation of economic policies that promote social justice and societal well-being. 


\section{Concluding remarks}

Labour policy has in many countries been subsumed under broader economic policies which, all too often, have come to be dominated by commercial and financial interests. Those defending such interests have been successful in propagating the idea that policies which advance their interests benefit all - a new version of trickle-down economics which suggests that workers do not even have to wait long, or at all, to receive the benefits of these wise policies. They claim there is a single Pareto-dominant set of policies, and therefore economic policy can simply be entrusted to technocrats, whose job is to craft that Pareto-dominant policy. For too long labour has acquiesced, sometimes becoming a more effective advocate of that Pareto-dominant policy than those whose interests it serves.

What I am calling for is not a return to class warfare, but a simple recognition of long-standing principles: there are trade-offs; there is uncertainty; different policies affect different groups differently; the role of the economic adviser is to inform policy-makers of the consequences of different decisions; and it is the role of the political process to make those decisions.

The fact that these principles have often been subverted has some important implications. While we all speak passionately about the importance of democratic principles, we also recognize that our democracies are imperfect, and that some groups' voices are heard more loudly than others. In the arena of international economic policy, the voices of commercial and financial interests are heard far more loudly than those of labour and consumer interests. As just noted, they have tried to convince others, with remarkable success, that there is no conflict of interests - which means that there are no trade-offs. The consequences speak for themselves: the growing dissatisfaction with the reform policies ${ }^{18}$ is partly a consequence of the fact that so many have actually been made worse off. In Mexico, for instance, the incomes of the poorest 30 per cent of the population have actually declined over the past 16 years. All of the income gains (reflected in increases in average GDP per capita) have occurred among the richest 30 per cent, and especially among the richest 10 per cent. According to the InterAmerican Development Bank, no country in Latin America for which data on income distribution are available can boast a decline in income inequality during the 1990 s (IDB, 2000). 
Government - and the international economic institutions, which are intergovernmental public institutions ${ }^{19}$ - play a role in determining the economic framework (including on those issues that affect labour relations). Therefore, one cannot separate politics from economics, as they are intimately intertwined. This was recognized by Teddy Roosevelt at the turn of the last century: his attack on trusts was not so much motivated by the loss of efficiency from the Harberger triangles resulting from monopoly power, as by the loss of democracy from the concentration of political power that follows from the concentration of economic power. The more stringent laws concerning the concentration of media power reflect similar concerns. Yet the economic policies that the international institutions have often pushed have resulted in the devastation of the middle classes and the aggrandizement of economic power. When national monopolies are sold prior to the establishment of effective regulatory and anti-trust institutions, those who hold these monopoly powers will use their wealth to perpetuate it. The Bill Gateses and the John D. Rockefellers of the world have clearly not been the strongest advocates of competition policy! The interplay between politics and economics has been seen most dramatically in Russia, where the privatization process resulted in the devastation of the middle class, and the creation of huge inequalities and an oligarchy which, if it seeks to establish a rule of law, will use its wealth and power to try to ensure that that rule of law favours itself. ${ }^{20}$

I have tried in this article to broaden the discussion beyond the confines of economics: there are market failures, and there is a role for government in correcting those market failures. Markets by themselves may fail not only to create full employment, but also to provide the right kind of working conditions. There are imperfections of competition and imperfections of corporate governance, and laws granting workers the rights to association and collective bargaining may serve to redress the balance, to give more effective voice to the concerns of workers, to enhance overall economic efficiency.

Advanced industrialized countries have developed a variety of institutions - including a strong independent academia, think tanks and NGOs - which give voice to broader national concerns, to the interests of consumers and workers, and which limit the scope, even if imperfectly, of special interests. This is not so in many developing countries.

19 They have been instrumental in perpetuating the myth that there is a single Pareto-dominant strategy - and the notion that economic policy is apolitical. Not only are they not supposed to enter into political matters (though they do so regularly and inevitably), they refer to the member governments as their shareholders, suggesting that they are more akin to corporations than to political institutions.

20 See Hoff and Stiglitz (2001) for a discussion of how macroeconomic and other policies induced policies of asset stripping rather than wealth creation, and enhanced the likelihood of success of policies that were more congenial to the former than the latter. 
Yet what is at stake for these countries is not just a matter of economic efficiency, but the kind of society into which they will evolve, and the creation or survival of meaningful political democracy. In other words, income distribution and the creation of institutions which give effective voice to the concerns of workers matter, not just for economic efficiency, but for the dynamics of political and economic change. To take but one example: land reform. In many countries of the world, land is highly inequitably distributed, and much of the land is held in the form of sharecropping. The 50 per cent share which farmers must pay attenuates incentives. Were a government to impose a 50 per cent tax, however, the international economic institutions would speak out loudly about the attenuation of incentives. The seeming lack of concern on the part of the IMF ${ }^{21}$ is hardly a surprise: land reform would disturb established economic interests and might even question existing property rights, regardless of how those property claims had come to be established. An even stronger case for land reform can be made: several of the most successful developing countries carried out major land reforms prior to - or at early stages of - their development transformation. With interests of trade unions coinciding with those of the landless, ${ }^{22}$ the two can be a potent force for land reform.

Development is more than just the accumulation of capital and the enhanced efficiency of resource allocation; it is transformation of society. Equitable, sustainable and democratic development requires basic labour rights, including freedom of association and collective bargaining.

If we, as an international community, are to promote equitable, sustainable and democratic development - development that promotes societal well-being and conforms to basic principles of social justice we must reform the international economic architecture. We must speak out more loudly against policies which work against the interests of workers. At the very least, we must point out the trade-offs, we must insist on democratic processes for determining how economic decisions are made. We have remained silent on these issues for too long - and the consequences have been grave.

\section{References}

Arnott, Richard J.; Stiglitz, Joseph E. 1985. "Labor turnover, wage structure and moral hazard: The inefficiency of competitive markets", in Journal of Labor Economics (Chicago, IL), Vol. 3, No. 4 (Oct.), pp. 434-462.

Blinder, Alan S. (ed.). 1990. Paying for productivity: A look at the evidence. Washington, DC, The Brookings Institution.

21 The World Bank has actually begun to push for market-based land reforms.

22 Land reform reduces migration pressure, which induces downward pressure on urban wages, 
Bruno, Michael; Easterly, William. 1996. "Inflation and growth: In search of a stable relationship", in Federal Reserve Bank of St. Louis Review (St. Louis, MO), Vol. 78, No. 3 (May-June), pp.139-146.

Card, David; Krueger, Alan B. 1995. Myth and measurement: The new economics of the minimum wage. Princeton, NJ, Princeton University Press.

Council of Economic Advisers. 1997. Economic Report of the President. Washington, DC.

-.1996. Economic Report of the President. Washington, DC,

Diamond, Peter. 1971. "A model of price adjustment", in Journal of Economic Theory (San Diego, CA), Vol. 3, pp. 156-168.

Eaton, Jonathan; Gersovitz, Mark. 1981. "Debt with potential repudiation: Theoretical and empirical analysis", in The Review of Economic Studies (Edinburgh), Vol. 48, No. 2 (Apr.), pp. 289-309.

Feldstein, Martin. 1998. "Refocusing the IMF", in Foreign Affairs (Palm Coast, FL), Vol. 77, No. 2 (Mar.-Apr.), pp. 20-33.

Greenwald, Bruce C; Stiglitz, Joseph E. 1993. "Financial market imperfections and business cycles", in Quarterly Journal of Economics (Cambridge, MA), Vol. 108, No. 1 (Feb.), pp. 77-114.

-; -. 1987. "Keynesian, new Keynesian and new classical economics", in Oxford Economic Papers (Oxford), Vol. 39, No. 1 (Mar.), pp. 119-133.

-; - 1986. "Externalities in economies with imperfect information and incomplete markets", in Quarterly Journal of Economics (Cambridge, MA), Vol. 101, No. 2 (May), pp. 229-264.

Hoff, Karla; Stiglitz, Joseph E. 2001. "Modern economic theory and development", in Gerald Meier and Joseph E. Stiglitz (eds.): Frontiers of development economics: The future in perspective. Oxford, Oxford University Press, pp. 389-459.

IDB (Inter-American Development Bank). 2000. Economic and social progress in Latin America: Development beyond economics. IPES 2000. Washington, DC.

Levine, David I. 1995. Reinventing the workplace: How business and employees can both win. Washington, DC, The Brookings Institution.

Murthi, Mamta; Orszag, Michael J.; Orszag, Peter R. 1999. The charge ratio on individual accounts: Lessons from the U.K. experience. Birbeck College Working Paper 99-2. London, University of London, Mar. [Available at http://www.econ.bbk.ac.uk/ ukcosts].

Orszag, Peter R.; Stiglitz, Joseph E. 2001. "Rethinking pension reform: Ten myths about social security systems", in Robert Holzmann and Joseph E. Stiglitz (eds.): New ideas about old age security: Toward sustainable pension systems in the 21st century. Washington, DC, World Bank, pp. 17-56.

Samuelson, Paul. 1997. Economics: The Original 1948 Edition. New York, NY, McGraw-Hill Professional.

Shapiro, Carl; Stiglitz, Joseph E. 1984. "Equilibrium unemployment as a worker discipline device", in American Economic Review (Nashville, TN), Vol. 74, No. 3 (June), pp. 433444.

Stiglitz, Joseph E. 1998. Towards a new paradigm for development: Strategies, policies and processes. Ninth Raul Prebisch Lecture, delivered at the Palais des Nations, Geneva, 19 Oct. Geneva, UNCTAD.

- 1997. "Reflections on the natural rate hypothesis", in Journal of Economic Perspectives (Nashville, TN), Vol. 11, No. 1 (Winter), pp. 3-10.

-. 1989. "The economic role of the State: Efficiency and effectiveness", in Arnold Heertje (ed.): The economic role of the State. Oxford, Basil Blackwell, pp. 9-85.

$-.1987 \mathrm{a}$. "The causes and consequences of the dependence of quality on prices", in Journal of Economic Literature (Nashville, TN), Vol. 25, No. 1 (Mar.), pp. 1-48.

-. 1987b. "Design of labor contracts: Economics of incentives and risk-sharing", in Haig Nalbantian (ed.): Incentives, cooperation and risk sharing. Totowa, NJ, Rowman \& Allanheld, pp. 47-68. 
-.1985a. "Credit markets and the control of capital", in Journal of Money, Credit and Banking (Columbus, OH), Vol. 17, No. 2 (May), pp. 133-152.

-.1985b. "Equilibrium wage distributions", in Economic Journal (Cambridge), Vol. 95, No. 379 (Sep.), pp. 595-618.

- 1983a. "Some aspects of the taxation of capital gains", in Journal of Public Economics (Lausanne), Vol. 21, pp. 257-294.

-.1983b. "Public goods in open economies with heterogeneous individuals", in JacquesFrançois Thisse and Henry G. Zoller (eds.): Locational analysis of public facilities. Amsterdam, North-Holland Publishing Company, pp. 55-78.

-.1974. "Alternative theories of wage determination and unemployment in LDCs: The Labor Turnover Model", in Quarterly Journal of Economics (Cambridge, MA), Vol. 88, No. 2 (May), pp. 194-227.

-; Weiss, Andrew. 1981. "Credit rationing in markets with imperfect information", in American Economic Review (Nashville, TN), Vol. 71, No. 3 (June), pp. 393-410.

World Bank. 2000. World Development Report, 2000/2001: Attacking poverty. Washington, DC. 
Copyright $@ 2002$ EBSCO Publishing 